\title{
Water transport and gas exchange in the non-vascular plant Dendroligotrichum dendroides (Brid. ex Hedw.) Broth. (Polytrichaceae, Bryophyta)
}

\author{
Transporte de agua e intercambio de gases en la planta no vascular Dendroligotrichum \\ dendroides (Brid. ex Hedw.) Broth. (Polytrichaceae, Bryophyta)
}

\author{
Cristian Atala
}

Laboratorio de Anatomía Funcional de Plantas, Departamento de Ciencia y Tecnología Vegetal (DCTV), Universidad de Concepción Campus Los Ángeles, Juan Antonio Coloma 0201, Los Ángeles, Chile.

catala@udec.cl

\begin{abstract}
RESUMEN
Se midió la conductancia hidráulica específica (Ks) y el intercambio de gases en individuos de D. dendroides (Polytrichaceae, Musci). Ks fue más alta que en algunas coníferas y comparable con algunas angiospermas leñosas, pero la fotosíntesis (Amax) fue relativamente baja. Los resultados muestran que una planta no vascular puede alcanzar altos valores de Ks, sugiriendo un funcionamiento "vascular" similar a las traqueófitas.
\end{abstract}

\section{INTRODUCTION}

Mosses are non-vascular plants, generally short, and lacking specialized vascular tissue. They are poikilohydric, meaning they are strongly dependent on environmental moisture (Proctor 1981). Mosses belonging to the Polytrichaceae present a conductive tissue analogous to xylem, and some species can reach $60 \mathrm{~cm}$ to ca. $1 \mathrm{~m}$ height. Several species of the Polytrichaceae have been studied regarding the anatomy of the stems and central strands (Tansley \& Chick 1901, Hébant 1975). Despite the morpho-anatomical complexity of these mosses, functional studies are rare, and for some species non-existent (Longton 1981, 1988, Proctor 1981, 1982, 2000, Proctor et al. 2007).

Tall moss species like Polytrichum, Dendroligotrichum and Dawsonia are regarded as endohydric (Buch 1945, 1947). This is because water is internally conduced through the central strand, although some external water movement can occur through capillary spaces in the leaves (Proctor 2000). The leaf specific conductivity (Kl) has been evaluated in Dawsonia superba Grev. (Polytrichaceae) and can reach up to $2.79 \mathrm{mmol} \mathrm{m} \mathrm{m} \mathrm{s}^{-1} \mathrm{MPa}^{-1}$, comparable to some pteridophytes, but 10 to 20 times lower than an angiosperm (Brodribb et al. 2007). Nevertheless, specific hydraulic conductivity of the stems of Polytrichaceae has never been quantified.
There is a positive relationship between hydraulic conductance and carbon gain (Meinzer \& Grantz 1990, Sperry \& Pockman 1993, Hubbard et al. 2001). The photosynthesis rate in some mosses is lower than in most vascular plants (Brodribb et al. 2007), with the exception of Polytrichum commune Hedw. that reach values similar to gimnosperms (Brodribb et al. 2007). Many of the meassured mosses lack a central strand of conducting tissue or are relatively small in size.

D. dendroides is a Polytrichaceae with a central strand of vascular tissue (Fig. 1) that grows in Chile from Arauco Province in the Bío-Bío Region to Tierra del Fuego in the Magallanes Region (Müller 2009). It grows in the understory of the temperate rainforest forming a strata where it competes with seedlings of vascular plants and other mosses (Juan Larraín, personal communication). In the northernmost part of its distribution, $D$. dendroides can experience temporal dessication, specially in the summer (Atala, unpublished data). This moss can reach up to $60 \mathrm{~cm}$ height (samples in CONC herbarium, Universidad de Concepción).

The present study addresses the hydraulic conductivity of the stems of $D$. dendroides, and its gas exchange parameters. It is hypothesized that, given the size and anatomy of this moss, it could functionally behave as a vascular plant. 


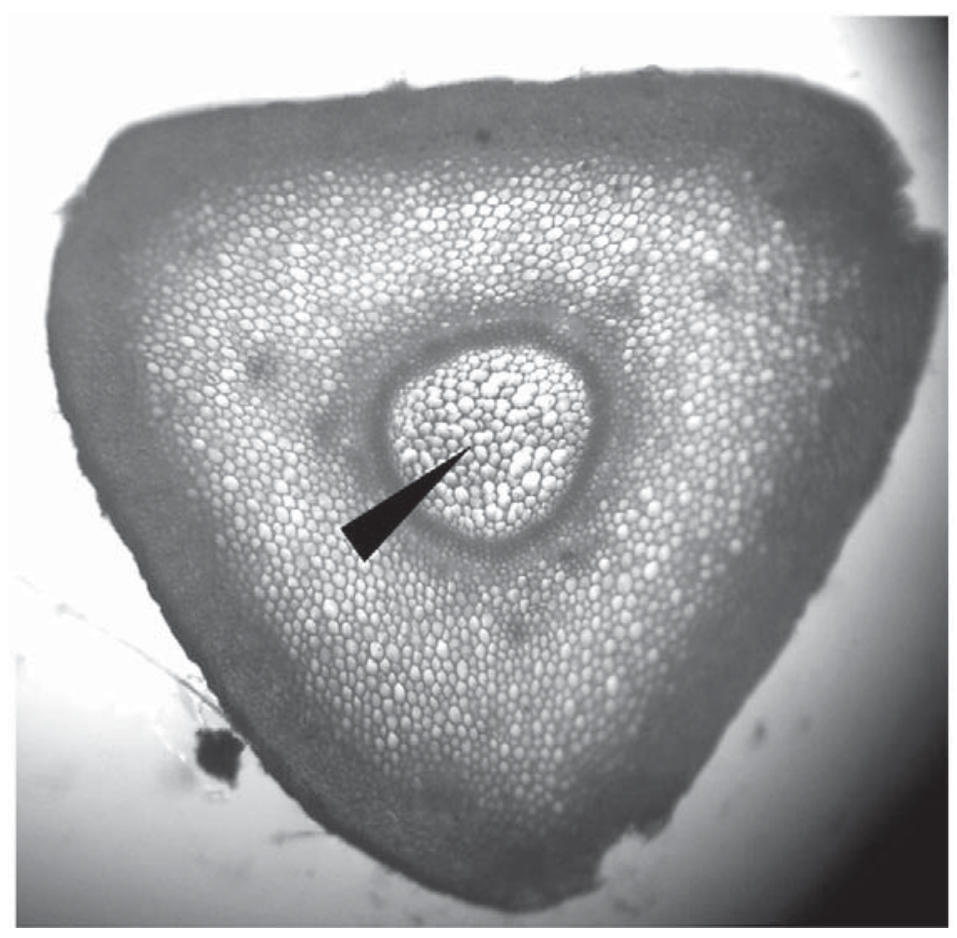

FIgURE 1. Cross section of the stem of $D$. dendroides. The arrow shows the central strand with hydroids. Photo taken at $100 \mathrm{X}$.

FIgURA 1. Sección transversal del tallo de D. dendroides. La flecha indica el haz central con hidroides. Fotografía tomada a 100X.

\section{MATERIALS AND METHODS}

Plant material

Individuals of $D$. dendroides (Brid. ex Hedw.) Broth. were collected growing in the understory of Monumento Nacional Contulmo (protected area), in the border of BíoBío and La Araucania Regions of Chile. It corresponds to a temperate forest with rains usually falling in the winter, and summer rainfall usually dropping below $35 \mathrm{~mm}$ and with occasional droughts (Di Castri \& Hajek 1976). Living plants were collected and then taken to the laboratory for analysis. Some individuals were put in a greenhouse for ecophysiological measurements.

\section{SPECIFIC WATER CONDUCTIVITY AND GAS EXCHANGE}

Individuals collected in the field were put in a greenhouse at Universidad de Concepción (Concepción, Chile) and were left for acclimatization for 2 weeks. They were maintained in constant moisture and under mild shade $(40 \%$ full light) to avoid dehydratation and stress. Specific water conductivity $(\mathrm{Ks})$ was determined for 10 individuals using a flowmeter with an integrated pressure-transducer. Plants were kept moist before and during the Ks measurements.
We also measured leaf specific hydraulic conductivity (K1) in the same individuals using the same instrument. To obtain $\mathrm{Kl}$ it was calculated the projected leaf area of a digital image of the plants using image measuring software (Sigmascan 5, SPSS, USA). Plants were hydrated when digitalized.

We conducted gas exchange measurements using an IRGA (CIRAS-II, PP Systems, Amesbury, MA, USA). Previous to measuring the maximum photosynthetic rate (Amax) we made light-response curves in 3 plants to obtain the amount of PAR radiation necessary to saturate carbon gain. We observed that $300 \mu \mathrm{mol} \mathrm{m}{ }^{-2}$ of PAR were enough to reach Amax, and that PAR was used in the estimation of Amax in other 5 individuals of $D$. dendroides. We also obtained evapotranspiration (E) and stomatal conductance $\left(\mathrm{g}_{\mathrm{s}}\right)$ in the same individuals. Instantaneous water use efficiency (WUE) was calculated as Amax/E. All measurements were conducted at $20^{\circ} \mathrm{C}$. These plants do not have stomata on their leaves, and stomatal conductance would roughly represent leaf-air conductance.

The light compensation point (LCP) and dark respiration rate $(\mathrm{Rd})$ were obtained from the light-response curves. Average values of the 3 individuals is reported. 
TABle I. Average \pm S.D. of hydraulic traits of D. dendroides, Sequoia sempervirens (gymnosperm), and Bahuinia variegata (woody angiosperm). $\mathrm{a}=$ data taken from Ambrose et al. 2009. b = data taken from Zhu \& Cao 2009.

TABLA I. Promedios \pm D.E. de rasgos hidráulicos de D. dendroides, Sequoia sempervirens (gimnosperma), y Bahuinia variegata (angiosperma leñosa). a = datos tomados de Ambrose et al. 2009. b = datos tomados de Zhu \& Cao 2009.

\begin{tabular}{lccc}
\hline \multicolumn{1}{c}{ TraIT } & D. dendroides (Bryophyte) & $\begin{array}{c}\text { S. sempervirens } \\
(\text { Gymnosperm) }\end{array}$ & $\begin{array}{c}\text { B. variegata } \\
\text { (woody Angiosperm) }^{\mathrm{b}}\end{array}$ \\
\hline $\mathrm{Ks}\left(\mathrm{Kg} \mathrm{s}^{-1} \mathrm{Mpa}^{-1} \mathrm{~m}^{-1}\right)$ & $1.78 \pm 0.3$ & $1.1 \pm 0.1$ & $2.07 \pm 0.1$ \\
$\mathrm{Kl} \mathrm{x} 10^{-4}\left(\mathrm{Kg} \mathrm{s}^{-1} \mathrm{Mpa}^{-1} \mathrm{~m}^{-3}\right)$ & $0.41 \pm 1.3$ & $5.3 \pm 0.8$ & $6.33 \pm 0.4$ \\
\hline
\end{tabular}

TABLE II. Average \pm S.D. gas exchange traits of $D$. dendroides. WUE $_{\mathrm{i}}=$ instantaneous water use efficiency. $\mathrm{LCP}=\mathrm{Light}$ compensation point. $\mathrm{Rd}=$ dark respiration.

TABLA II. Promedios \pm D.E. de intercambio de gases de $D$. dendroides. WUE $_{\mathrm{i}}=$ eficiencia en el uso del agua instantánea. $\mathrm{LCP}=$ punto de compensación de luz. $\mathrm{Rd}=$ respiración oscura.

\begin{tabular}{cc}
\hline Trait & Average \pm S.D. \\
\hline Amax $\left(\mu \mathrm{mol} \mathrm{m}^{2} \mathrm{seg}^{-1}\right)$ & $2.5 \pm 0.39$ \\
$\mathrm{E}\left(\mathrm{mmol} \mathrm{m}^{2} \mathrm{seg}^{-1}\right)$ & $0.72 \pm 0.05$ \\
$\mathrm{~g}_{\mathrm{s}}\left(\mathrm{mmol} \mathrm{m}^{2} \mathrm{seg}^{-1}\right)$ & $603.6 \pm 551.24$ \\
$\mathrm{WUE}_{\mathrm{i}}$ & $3.47 \pm 0.50$ \\
$\mathrm{LCP}\left(\mu \mathrm{mol} \mathrm{m} \mathrm{seg}^{-1} \mathrm{PAR}\right)$ & $15.22 \pm 3.30$ \\
$\mathrm{Rd}$ & $2.33 \pm 0.06$ \\
\hline
\end{tabular}

\section{RESULTS}

The stems of $D$. dendroides can reach high $\mathrm{Ks}$ and $\mathrm{Kl}$ (Table I). These specific hydraulic conductivity measures were highly dependent on moisture status. After a few minutes plants began to dehydrate and Ks dropped rapidly. After rehydration Ks values increased (data not shown). Despite the high water conductivities, gas exchange parameters were relatively low (Table II).

\section{DISCUSSION}

The moss $D$. dendroides is a non-vascular plant. Nevertheless, this plant has a specialized vascular tissue that can achieve very high hydraulic conductivity (Table I). The Ks values for this moss are higher than many conifers and comparable to some angiosperms (Table I, Ambrose et al. 2009, Zhu \& Cao 2009). The high Ks could partially account for the large plant height (for a bryophyte). Biophysically, a plant without vascular tissue can only reach a few centimeters high, because of the diffusion limitations that increase with plant size (Vogel 2003).
Despite the high Ks, Amax values were relatively low, but comparable to other Polytrichaceae of similar size like Dawsonia superba (Brodribb et al. 2007). Both the Kl and Amax found in $D$. dendroides are within the range of other studied mosses (Brodribb et al. 2007). The low Amax and E could be due to plant mechanisms to reduce photosynthesis when water potential drops, since they lack stomata in the gametophyte leaves to control water loss (Zeiger et al. 1987). The lack of stomata could also explain the high gs values since water is loss trough the whole surface of the leaf. This plant is usually found in understory, in relatively shaded areas (Atala \& Parra, unpublished data). The relatively low Amax, LCP, and Rd also suggest that this is a shade-tolerant species, usually presenting intrinsically low carbon gain rates (Givnish 1988; Valladares \& Niinemets 2008).

This non-vascular plant has an organized conducting tissue with high specific hydraulic conductivity. In the field this plant could functionally behave as a vascular plant, competing and sometimes dominating the understory in the temperate forest of Chile. More functional and ecological studies are needed to fully understand the ecophysiology of Polytrichaceae, particularly of $D$. dendroides. 


\section{ACKNOWLEDGMENTS}

Study funded by project DIUC 209.415.012-1.0. Thanks to Tim Brodribb for the flowmeter measurements.

\section{REFERENCES}

Ambrose, A.R., C. Stephen, S.C. Sillett \& T.E Dawson. 2009. Effects of tree height on branch hydraulics, leaf structure and gas exchange in California redwoods. Plant Cell \& Environment 32: 743-757.

BrodribB, T.J., T.S. Feild \& G.J. Jordan. 2007. Leaf Maximum Photosynthetic Rate and Venation Are Linked by Hydraulics. Plant Physiology 144: 1890-1898.

Buch, H. 1945. Über die wasser-und mineralstoffversorgung der moose. Part 1. Commentationes Biologicae Societas Scientiarum Fennicae 9(16): 1-44.

Buch H. 1947. Über die wasser-und mineralstoffversorgung der moose. Part 2. Commentationes Biologicae Societas Scientiarum Fennicae 9(20): 1-61.

Castri, F. Di, \& E.R. Hajek. 1976. Bioclimatología de Chile. Editorial Universidad Católica de Chile, Santiago, Chile. $128 \mathrm{pp}$.

GivnISH, T.J. 1988. Adaptation to sun and shade: a whole-plant perspective. Australian Journal of Plant Physiology 15: 63-92.

HÉBAnt, C. 1975. Organization of the conducting tissue-system in the sporophytes of Dawsonia and Dendroligotrichum (Polytrichales, Musci). Journal of the Hattori Botanical Laboratory 39: 235-254.

Hubbard, R.M., V. Stiller, M.G. Ryan \& J.S. Sperry. 2001. Stomatal conductance and photosynthesis vary linearly with plant hydraulic conductance in ponderosa pine. Plant Cell \& Environment 24: 113-121.

Longton, R.E. 1981. Physiological ecology of mosses. In: R.J. Taylor \& S.E. Leviton (eds.), The mosses of North America, pp. 77-113. American Academy of Science,
Pacific Division, Washington, USA.

Longton, R.E. 1988. The biology of polar bryophytes and lichens. Cambridge University Press, Cambridge, UK. 391 pp.

Meinzer, F.C. \& D.A. Grantz. 1990. Stomatal and hydraulic conductance in growing sugarcane: stomatal adjustment to water transport capacity. Plant Cell \& Environment 13: 383-388.

Müller, F. 2009. An updated checklist of the mosses of Chile. Archive for Bryology 58: 1-124.

Proctor, M.C.F. 1981. Physiological ecology of bryophytes. Advances in Bryology 1: 79-166.

Proctor, M.C.F. 1982. Physiological ecology: water relations, light and temperature responses, carbon balance. In: A.J.E. Smith (ed.), Bryophyte Ecology, pp. 333-381. Chapman \& Hall, London, UK.

Proctor M.C.F. 2000. Physiological Ecology. In: A.J. Shawn \& B. Goffinet, Bryophyte Biology, pp. 225-247. Cambridge University Press, Cambridge, UK.

Proctor, M.C.F., R. Ligrone \& J.G. Duckett. 2007. Desiccation tolerance in the moss Polytrichum formosum: physiological and fine-structural changes during desiccation and recovery. Annals of Botany 99: 75-93.

Sperry, J.S. \& W.T. PockMAN. 1993. Limitation of transpiration by hydraulic conductance and xylem cavitation in Betula occidentalis. Plant Cell \& Environment 16: 279-287.

TAnsley, A.G. \& E. CHICK. 1901. Notes on the conducting tissuesystem in Bryophyta. Annals of Botany 15: 1-38.

Valladares, F. \& Ü. NiInEMETs. 2008. Shade tolerance, a key plant trait of complex nature and consequences. Annual Review of Ecology, Systematics and Evolution 39: 237-257.

Vogel, S. 2003. Comparative Biomechanics: Life's Physical World. Princeton University Press, Princeton, NJ. 580 pp.

Zeiger, E., G. Farquhar \& I. Cowan. 1987. Stomatal Function. Stanford University Press, Stanford, CA. 520 pp.

Zhu, S.-D. \& K.-F. CAO. 2009. Hydraulic properties and photosynthetic rates in co-occurring lianas and trees in a seasonal tropical rainforest in southwestern China. Plant Ecology 204: 295-304.

Recibido: 24.08 .10

Aceptado: 01.10.10 